\title{
機能性溶射皮膜の酸素センサへの応用
}

浦 田 邦 芳*

\section{Application of Functional Ceramic Coating to Oxygen Sensor}

Kuniyoshi URATA*

Key Words : Oxygen Sensor, Functional Ceramic Coating, Plasma Spray Technique

\section{1.はじめに}

金属表面の保護技術としての溶射は，施工にかなりの 技術を要すること，また材料す含めたランニングコスト が比較的高いことから，一般に普及するにはいたってい ないがロールの耐摩耗, タービン・フィンやスペースシャ トルの耐熱コーティングなど, 塗装やめっきでは対応で きないきびしい条件下での応用に欠かせない技術となっ ている。 また最近では，これまで接合の困難なものと されていた金属とセラミックスの接合, セラミックスの 持つ機能特性を生かす機能性溶射の対応など, 新しい利 用例も実施されているが，溶射の本質は母材に影響を与 えず機能を付加させる表面改質技術と言えるだろう。こ こではその一例として, 溶鋼用消耗型酸素センサへの溶 射技術の応用について話を進めたい。

\section{2. 酸素センサの原理}

製鋼用酸素センサは, 溶鋼中の溶解酸素濃度を酸素濃 淡電池を利用して測定するもので, 溶鋼の脱酸処理など 操業に広く使用されている。1）式にその電池式を示す。

$\mathrm{M}, \mathrm{Po}_{2}(\mathrm{oinFe})$ /固体電解質／ $\mathrm{Po}_{2}(r e f), \mathrm{M} \cdots 1$ )

ここでMはリード, $\mathrm{O}\left(\mathrm{Po}_{2}\right)$ は溶解酸素濃度（酸素分 圧), $\mathrm{Po}_{2}$ (ref) は, 基準となる酸素分圧である。この電 池の起電力 $\mathrm{E} は$ 次のネルンストの式により示される。

$$
\mathrm{E}=\frac{\mathrm{RT}}{4 \mathrm{~F}} \ln \frac{\mathrm{Po}_{2}}{\mathrm{Po}_{2}(\text { ref })}
$$

$\mathrm{R}$ : ガス定数, $\mathrm{F}:$ ファラデ定数, $\mathrm{T}$ : 溶鋼温度 $(\mathrm{K})$

従って, 基準となる酸素分圧 $\mathrm{Po}_{2}(r e f)$ をその值が既 知な金属一金属酸化物の平衡酸素分圧とすれば, 起電力 $\mathrm{E}$ と温度Tを测定することにより, 溶鋼中の酸素量が逆 算できる ${ }^{1}$ 。

*山里エレクトロナイト(侏)研究所(三566 大阪府摂津市南別府町 1264-1, 06-349-2130)

Yamari Electronite Co., Ltd. (1264-1, Minami-befu-cho, Settsu-shi, Osaka 566)
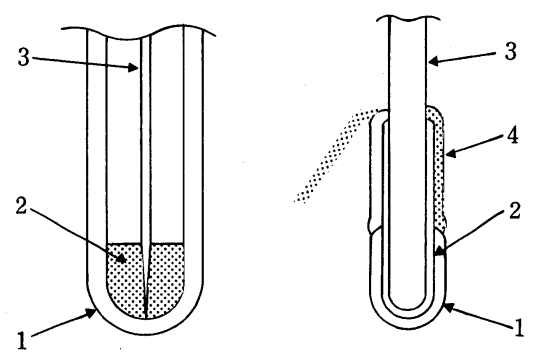

a) 焼結体型

b) ニードルセンサ

1. 固体電解質 (安定化ジルコニア)

2 ，基準極 (金属一金属酸化物)

3.リード棒 (母材)

4. 部分コーティング (アルミナ)

図 1 酸素センサの模式図

\section{3. 溶射を用いた構成とその成果}

さて酸素センサは熱電対ととあに適当な外装材に組み 込まれてプローブとなり, 直接溶鋼に浸せきされる。図 1 a ）は固体電解質にジルコニア焼結体を用いた酸素セ ンサの構造を示す。このジルコニアは直接溶鋼と接触す る。そこでジルコニア焼結体は耐熱衝撃性の高い部分安 定化したものを用いる必要があり，また溶鋼中で対流な ごの機械的応力に耐えるために $1 \mathrm{~mm}$ 弱の厚みが必要之 なる。この 2 つ電池の熱平衡を大きく左右する因子で, センサの応答性に直接影響を及ぼす ${ }^{2,3)}$ 。ジルコニアの安 定化度が高いほど，また厚みの薄いほど応答時間が短く なり，プローブ外装材の簡略化などによりコストパフォー マンスは大きくなるのである。図 $1 \mathrm{~b}$ ）はプラズマ溶射 で構成したニードルセンサである。ブラスト処理したモ リブデンリード $(\phi 1.8 \mathrm{~mm})$ 上にまずクロム/クロミ ア層 $(0.2 \mathrm{~mm})$ を, 次に完全安定化ジルコニア皮膜 $(0.4$ $\mathrm{mm})$ を溶射し, 外径は従来の $2 / 3(3 \mathrm{~mm})$ である。 （図 2 ）溶射皮膜の持つ積層構造は, 熱膨張などによる 内部応力に対しての緩衝効果が大きく, 耐熱衝撃性が高 


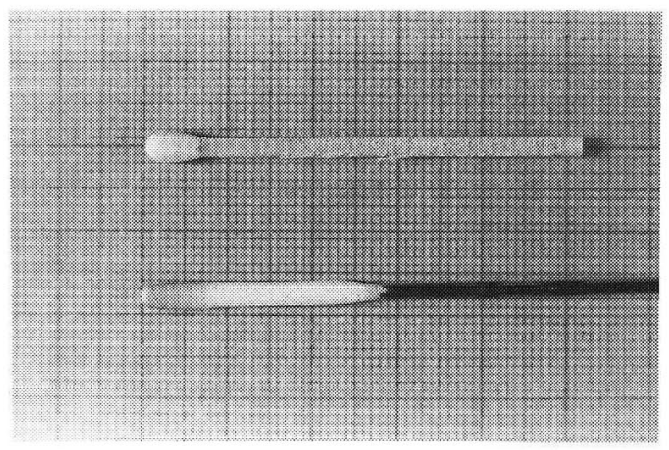

図 2 ニードルセンサ

まっているので, 完全安定化ジルコニアが使用できる。 また母材のモリブデンリードに機械的強度があるので, ジルコニア皮膜を極力薄くすることが可能となる。図 3 にはジルコニア皮膜の厚みと応答時間の関係を示してい る。肉厚 $0.4 \mathrm{~mm}$ までは薄くなるに従って応答時間が短 縮されていることが分かる。

\section{4. 表面処理技術からみたニードルセンサ}

これまでは, 酸素センサの立場から, ニードルセンサ の説明をしてきた。つぎに表面処理技術の 1 つとしての 溶射からニードルセンサを見てみたい。

まず第 1 に径 $1.8 \mathrm{~mm}$ のモリブデン棒上に先端まで含 めて, 均一な溶射皮膜を構成するためには, 溶射フレー ムの収束, 安定性, ムラのない溶射材料の供給, 皮膜を 均一にするための母材および溶射ガンの移動や溶射角度 の調整など人間の観察と自動制御を組み合わせ, 溶射と いう作業としては敩しすぎるくらいの製造管理が必要で ある。これは特にニードルセンサが表面研磨等の後加工 が全く許されない製品であることとあ関係している。

第 2 に金属母材上にボンディング効果を持つト地層を

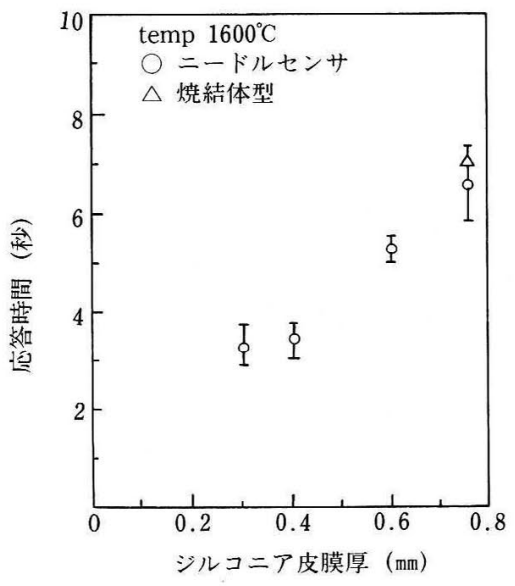

図 3 皮膜厚と応答時間の関係
おき, 耐熱・耐摩耗性酸化物皮膜を付けることは, 通常 のセラミック溶射には欠かせ妨のである4)。しかし， ニードルセンサの場合にはクロム/クロミア層は下地で あると同時に酸素濃淡電池の基準酸素分圧を決めるもの であり, ジルコニア層は内部のモリブデンリードや下地 層を溶鋼の侵食加ら守る耐熱皮膜であると同時に酸素イ オン伝導体でなければならない。このように溶射皮膜の 下地層, 耐熱コーティング層にさらに酸素濃淡電池の基 準極, 酸素濃淡電池の固体電解質という機能が付加され たことが溶射の応用製品としては新しい存在とされるゆ えんである。

第 3 に酸素濃淡電池を応用した化学センサとして用い られる以上, 電池反応が安定していることが必要で, 溶 射材料中に不純物はもちろん, 皮膜自身のち密性, 接着 強度に有効なものであ反応を阻害するような成分, 例え ばチタニア・アルミナなどは厳しく管理されなければな らない。ニードルセンサにおける溶射皮膜は“はがれず に付いている”ことよりも“酸素濃淡電池の構成部とし て安定している”ことのほうが重要であり，こうした成 分の混入や組成のばらつきは命取りになってしまうから で，ニードルセンサでは市販の溶射材料を使わず専用の 溶射粉末を使用している。

以上の 3 点をまとめると, 材料固有の特性を皮膜特性 として安定化させる（機能性溶射）という観点から新し い溶射材料の開発を行い, その材料を使って小さな母材 に均一な皮膜を溶射する施工技術を確立することによっ て，新しい溶射応用製品が誕生したといえる。

\section{5. おわりに}

溶射を利用した酸素センサの構成は実は 15 年以上も前 に考案されているが, 実用化されたのはほんの数年前の 事である。その間, 単なる被覆としての溶射皮膜ではな く，機能性皮膜を溶射できる施工方法の進歩があって完 成にたどり着いた。現行の溶射技術の応用ではなく，新 しい製品を作り出すために半ば強制的に溶射における管 理，技術レベルをアップしてきたということである。技 術発展の一つの形と言えるのではないだろうか。

最後に，表面技術という題材からはややはずれた内容 だったかむ知れないが, 治金屋の一つの挑戦だったとい うことでご容赦願いたい。読者諸兄の何かのお役に立て れば幸いである。

(1988-10-17 受理)

\section{文献}

1) 後藤; 電気化学, 50, (1) 54(1982)

2) 中村 他 ; 日本金属学会報, 25, (4),274(1986)

3) 小坂 他; 鉄と鋼, 69,(14),(1983) S965

4）セラミックコーティング技術；(森総合技術センター(1984) 